\title{
EFFeCts of Domestic Livestock AND WildLife Grazing in Grand Teton National Park
}

\author{
Michael A. Smith $\uparrow$ JeRrold L. Dodd \\ RANGe MANAgEMENT DEPARTMENT $\downarrow$ UNIVERSITY OF Wyoming \\ LARAMIE
}

\section{$\downarrow \quad$ INTRODUCTION}

The Snake River plains and foothill areas of Jackson Hole have been grazed by domestic livestock since settlement of the area. Wildlife populations, including elk (Cervus elaphus), buffalo (Bison bison), mule deer (Odocoileus hemionus), and antelope (Antilocapra americana) have historically used the area. Moose (Alces alces) are currently relatively abundant. Currently, livestock continue to use part of the area contained in Grand Teton National Park either as a concession or due to authorization by Park enabling legislation. Large grazing wildlife also inhabit the Park area. Park managers need information concerning the effects of grazing by large ungulates on vegetation resources, to achieve desired plant community goals by effectively managing grazing.

\section{$\downarrow$ ОвJeCtives} follows:

The objectives of this research are summarized as

1. Determine kind and location of important potential natural plant communities (PNC's) within a study area, largely defined by areas of current use by livestock, east of the Snake River, and adjacent comparable areas used only by wildlife, west of the river.

2. Compare current vegetation composition on representative sites used by livestock and wildlife. Compare potential vegetation composition for these sites with an emphasis on comparisons of livestock and wildlife effects.

3. Estimate forage utilization on key sites and map utilization patterns.

4. Establish permanent vegetation trend monitoring transects.

5. Provide grazing management recommendations to the Park Service, to assist them in reaching vegetation management goals.

\section{$\downarrow$ MethodS}

Authorization to begin this effort was received in mid-summer 1990. Starting this date limited data collection. A reconnaissance of the area was conducted with Park managers to identify general areas of use and their concerns. Later, principal investigators covered most areas of interest on foot or horseback to ascertain general patterns of soils, vegetation composition and use, and grazing animal distribution. The Park Service soil scientist provided assistance in interpreting soils information. 
Specific areas examined in early August, with respect to potential for high use by grazing animals and need for detailed vegetation analysis and monitoring included:

1. Upland plains west of the Snake River, grazed only by wildlife

2. Floodplains (Cottonwood lowlands) west of the Snake River, grazed only by wildlife

3. Pacific Creek drainage to the Park boundary, grazed by cattle and wildlife.

4. Elk Ranch Reservoir area, grazed by cattle and wildlife.

5. Floodplains east of the Snake River in the Triangle $\mathrm{X}$ horse pasture, grazed by horses and wildlife.

6. Antelope Flats, upland plain east of the Snake River, grazed by cattle during trailing to summer pasture and wildlife.

7. Other areas yet to be examined include Mormon row and Blacktail Butte pasture.

\section{$\downarrow \quad$ ResUlts}

Results to date are based only on field observations as utilization and trend transects have yet to be installed.

Upland plains west of the Snake River consist of a uniformly complex area of 2 drouthy soils dominated by low and big sagebrush (Artemisia arbuscula and A. tridentata). Utilization of vegetation appeared to be light. Elk and buffalo were sighted in the area.

Floodplains west of the Snake River and adjacent to the Triangle $\mathrm{X}$ pasture were a complex association of vegetation types including cottonwood (Populus angustifolia) dominated lowlands, wet/subirrigated areas, and sagebrush dominated communities. Live willows (Salix sp.) were uncommon and cottonwoods were dominated by a single mature age class. Herbaceous plants were heavily utilized. Elk and buffalo were abundant.

The Pacific Creek drainage appeared to have received little use by cattle. Riparian zones were dominated by apparently healthy willow stands. A few cattle were seen along the Park boundary with National forest lands.

The Elk Ranch Reservoir area has a variety of terrain and vegetation types including wet/subirrigated riparian zones, sagebrush dominated communities, and aspen communities. Utilization patterns of forages suggest an uneven distribution of grazing pressure. Riparian zones and adjacent sagebrush dominated valley floor and gentle slopes had been heaviest used. Dense sagebrush on surrounding hills appears to limit cattle use of these areas. Cattle were primarily in the irrigated meadows at the time of our visit. We noticed several situations where management actions could be easily undertaken to improve cattle distribution and reduce grazing pressure on native riparian, valley bottom sagebrush communities, and irrigated meadows without reducing stocking rates. These actions include intensified use of the irrigated meadows (perhaps by additional subdivisions), salting and/or herding to move cattle away from the reservoir and riparian zones along Uhl Draw, and burning dense sagebrush stands on adjacent hills to attract cattle.

The Triangle $\mathrm{X}$ horse pasture along the Snake River is largely cottonwood dominated lowland with areas of wet/subirrigated vegetation, and an area of sagebrush dominated upland. Willows were common in wetter areas and a mixture of age classes of cottonwoods was apparent. Utilization of herbage was light to moderate. Horse tracks and trails indicated grazing was ongoing, apparently at night.

The Antelope Flat area has an exceptionally uniform soil with sagebrush dominated vegetation type. Similar but smaller areas of the same soils had been observed west of the River. Utilization of forages had been minimal and the only evidence of trailing was along the dirt road on the east of the area.

The areas identified above except Pacific Creek and including the Blacktail Butte pasture appear to be the most important areas for installation of utilization and trend monitoring studies because of the obvious probabilities for grazing use and apparently altered plant community composition of a few locations. The soils mapping units for the upland area in the published soil survey by the Soil Conservation Service appear to be accurately described and located. Some additional mapping of soils may be desirable in lowland and wet areas. These mapping units should suffice as a basis for identification of PNC's although additional soilPNC correlation may be necessary. Complex mapping units (2 or more soil types) will require additional stratification in conjunction with locating vegetation sampling sites to insure correct identification of PNC for sampling locations.

Utilization and trend monitoring transects will be installed at the earliest opportunity in the coming spring (1991). Sampling of PNC's will begin with sufficient development of vegetation phenology. 